\title{
El currículum ocult en els manuals de llengua i literatura. El personatge literari com a símptoma
}

\author{
JAVIER VELLÓN LAHOZ (vellon@uji.es) \\ Universitat Jaume I
}

\section{Introducció}

L'anàlisi del currículum ocult dels llibres de text afecta no sols els continguts d'una matèria concreta, sinó tot el discurs didàctic que es manifesta en els diversos nivells de concreció curricular, des del marc legislatiu fins als diferents àmbits d'actuació en els centres educatius i, per descomptat, a la pràctica del docent i a la seua competència professional.

En aquest marc epistemològic, la revisió dels manuals de Llengua i Literatura, i més concretament d'un dels seus blocs més controvertits, el de la història de la literatura, ha de tenir present les propostes concretes en el terreny dels continguts, però també l'entorn curricular i l'actualització puntual per part de departaments i de programacions d'aula, en les quals el manual es converteix en un índex sobre el qual convergeixen totes les orientacions discursives.

D'aquesta manera, un treball com el que ací es presenta ha d'afrontar una de les qüestions més debatudes en la bibliografia pedagògica: la rellevància dels llibres de text en l'acció educativa, en la mesura que en l'actualitat «no son solamente recursos para ser usados por el profesor y los alumnos, sino que pasan a ser los verdaderos vertebradores de la práctica pedagógica» (Gimeno Sacristán, 1988: 187).

Més encara quan, fins i tot en la situació present, amb tots els canvis instigats per les successives reformes educatives i curriculars, amb la incorporació de les TIC, amb la formació del professorat en els principis del constructivisme, amb la integració curricular i amb l'enfocament comunicatiu, la presència del llibre de text és tal que continuen vigents les tendències observades en el seu moment per Apple (1989: 91): «Se estima que el 75\% del tiempo que los estudiantes de primaria y secundaria pasan en el aula y el $90 \%$ del tiempo que dedican a los deberes está ocupado por materiales de texto».

Aquesta preponderància del llibre de text el converteix en un àmbit privilegiat per a l'estudi del currículum ocult, entés com «el conjunto de normas, actitudes, expectativas, creencias y prácticas que se instala de forma inconsciente en las estructuras y el funcionamiento de las instituciones y en el establecimiento y desarrollo de la cultura hegemónica de las mismas» (Santos Guerra, 1997: 16).

Aquest article analitza, en aquesta línia, els implícits sexistes en els llibres de text de Llengua i Literatura de 3r d'ESO — vegeu més avall la relació d'obres estudiades -, i més concretament el bloc d'història de la literatura dedicat a l'edat mitjana i al Segle d'Or. L'objectiu del treball és l'anàlisi del tractament de personatges i d'altres funcions del discurs de ficció, com són el narrador i el destinatari, els temes-tòpics, etc. 
L'elecció d'aquest aspecte tan puntual obeeix al fet que constitueix un dels camps més controvertits en els debats sobre la didàctica de la literatura en el marc dels nous vessants, els que orienten la didàctica de la llengua cap a l'enfocament comunicatiu. La història de la literatura en els cursos superiors de l'ESO - com veurem més endavant- es mostra com l'apartat menys permeable als postulats comunicatius, centrats en l'activitat de l'alumnat enfront del domini de la classe magistral i, per tant, el més vinculat amb el seguiment de les orientacions oferides pel manual, tant en el que afecta els dictats teòrics, com les activitats, lectures, exercicis, etc.

No obstant això, és necessari plantejar una sèrie de premisses determinants per a fixar les claus del present treball:

- L'objectiu de l'anàlisi no és el tractament sexista del llenguatge - encara que alguna apreciació es farà respecte d'això-, tant el verbal com el visual, sobretot perquè s'ha avançat molt en aquest terreny i resulta més significatiu l'estudi de l'orientació dels continguts, ajustats a un cànon literari didàctic que reprodueix la successió cronològica d'obres, èpoques i autors semblants. Per això, la finalitat del treball és qüestionar el model sobre el qual se sustenta l'esmentat cànon a partir de les directrius tradicionals, basades en una historiografia que no es deté en perspectives alternatives capaces d'oferir un punt de vista equilibrat des del vessant sexista.

- En aquest sentit, no es tracta de realitzar una auditoria sobre la presència/absència d'escriptores en els llibres de 3r d'ESO - seguint el model de López-Navajas (2014) i López-Navajas i Querol (2014) -, quelcom que té molt d'anecdòtic en l'època en què se centra aquest estudi, sinó que pretén anar més enllà, fins als fonaments que vertebren el model de coneixement literari que s'imparteix en secundària: com se seleccionen els temes d'una etapa i quin tractament se'ls dóna; si hi ha l'objectiu de traçar una equidistància entre la presència de l'home com a subjecte literarinarrador, lector, personatge i la de la dona; si es trasllada el protagonisme femení en gèneres literaris concrets a les pàgines dels manuals; si s'exposen els motius culturals que impulsen els comportaments sexistes en una societat, tal com s'observa en les seues manifestacions literàries i artístiques.

- La història de la literatura és també un espai didàctic privilegiat per a programar des d'una òptica innovadora i promoure un currículum integrat, amb continguts transversals en què es planteja una metodologia capaç d'adaptar a l'aula una educació en valors, entesa com una pedagogia dirigida a generar un sistema crític amb què «enjuiciar la realidad e intervenir en ella para transformarla y mejorarla» (Yus Ramos, 1995: 72). En aquesta línia, la pedagogia de l'empoderament es funda en la confluència entre el pla emocional i el pla academicointellectual, per a la qual cosa és necessari un enfocament integrador, transversal, que apunte cap a l'educació globalitzadora (Yus Ramos, 1997).

Amb aquest fi, la programació didàctica centrada en la història de la literatura ha de transcendir la inèrcia positivista i de mera erudició acrítica per a promoure activitats que situen la dona en un pla semblant al de l'home, no sols en la selecció de continguts, sinó relativitzant i contextualitzant les raons que en cada època expliquen la fixació del rol femení a través de les pràctiques culturals, i establir parallelismes amb l'actualitat. 


\section{Didàctica de la literatura i llibres de text}

En un aclaridor recorregut per les premisses sobre les quals s'estableixen els models didàctics de la literatura, Colomer (1996) determina que, enfront dels corrents anglosaxons, a Espanya posseeix una gran tradició en les aules l'estudi historiogràfic de la literatura com a patrimoni cultural, des d'una visió pròxima al «manual de historia con fragmentos antológicos y ejercicios explicativos» (Colomer, 1996: 124).

Aquesta orientació ha estat vinculada a un model didàctic basat en l'erudició, en la transmissió de dades, en continguts conceptuals lligats a la metodologia de la classe magistral, amb recursos auxiliars centrats en el comentari de text guiat com a illlustració de la teoria.

La consequiència és que aquest apartat de la programació s'ha mantingut al marge de la resta de blocs relacionats amb la llengua i l'anàlisi del discurs, aquests sí, més proclius a l'aplicació de temptatives innovadores, fins al punt de representar la disciplina més sotmesa a les directrius dels manuals, mitjançant les quals «los maestros hacen de meros instrumentos de aplicación» (Mendoza Fillola, 1998: 240).

La veritat és que els currículums de les diferents reformes han proposat un canvi estratègic centrat en els nous corrents de didàctica de la literatura, pròxims a l'enfocament comunicatiu - treballar les competències de l'alumnat en l'esfera de l'expressió i la interpretació creativa - i al constructivisme, açò és, convertir el discent en protagonista de l'acte d'aprenentatge a partir de les seues capacitats i de la seua activitat.

Per citar només els més recents (currículum LOE, en el seu desenvolupament a la Comunitat Valenciana -Decret 112/2007-, i el de la LOMQE, Decret 87/2015), en ambdós es reconeix la contribució de l'estudi de les obres literàries «al desenvolupament d'una competència artística i cultural, entesa com a aproximació a un patrimoni literari i a uns temes recurrents que són expressió de preocupacions essencials de l'ésser humà» (LOE). Per a això, el tractament dels fenòmens literaris ha de contemplar-se a partir de pressupòsits que deixen enrere el model estrictament historiogràfic:

- Enfocar l'estudi i el treball sobre la literatura a partir de temes i de tòpics («Utilitzar els coneixements literaris en la comprensió i la valoració de textos breus [...] atenent la presència de certs temes recurrents» LOE).

- «Pervivència i evolució de personatges-tipus, temes i formes» (LOMQE).

- Establir relacions entre obres i «interpretació del sentiment humà implícit en les obres comparades» (LOMQE).

- «Connexió entre la literatura i la resta d'arts [...] relacionant obres, personatges i temes universals» (LOMQE).

Es tracta, en definitiva, d'incorporar a l'aprenentatge significatiu de la literatura les aportacions d'iniciatives innovadores de la crítica literària, com ara la tematologia, hereva de la intertextualitat i de la literatura comparada, com a principi interpretatiu de les connexions en l'àmbit de la creació, i que han donat lloc a nocions de molta operativitat en el terreny de la formació literària com la «d'intertext discursiu» $\mathrm{i}$ «intertext lector» (Mendoza Fillola, 2011), els quals permeten transcendir els límits de la història de la 
literatura per a connectar-se amb els eixos primordials de l'enfocament comunicatiu: «el concepto de interxto lector aporta nuevas orientaciones para dinamizar la formación del lector hacia una conocimiento significativo de la literatura» (Mendoza Fillola, 2011: 58).

A més, aquestes tendències faciliten programacions dirigides a la integració, a la transversalitat i a la formació en valors, no sols en el vessant literari (la literatura comparada, per exemple, molt rellevant en comunitats amb dues tradicions), sinó en la de qualsevol tipus de manifestacions socials, culturals, polítiques, etc.

La realitat, no obstant això, és que en el cas concret de la història de la literatura -en el domini de la formació del llenguatge literari, en els cursos inicials de l'ESO, així com en les estratègies d'animació lectora, s'ha avançat molt en els últims anys- el que encara predomina en l'aula és el panorama descrit per Salvador (2000: 127):

Ja és ceguesa o frau qüestionar-se sols continguts - les dades memoritzables - d'unes assignatures, en lloc de redissenyar les connexions transversals i la mateixa concepció de l'ensenyança per al segle que ens arriba. És així una història, una geografia o una literatura més semblant als concursos de paleotelevisió que a les eines escaients per comprendre la societat i la persona.

Quina és la responsabilitat dels llibres de text en el manteniment d'aquestes rutines allunyades del model comunicatiu? Per a contestar aquesta qüestió, en primer lloc, cal plantejar la contribució d'aquestes obres, molt rellevants en el mercat editorial i en la pràctica docent, en la consolidació del cànon literari.

El concepte de cànon, com recorda Pozuelo Yvancos (1996: 3), està relacionat amb el «d'història literària» i, per tant, amb l'ensenyament de la literatura. A partir del segle XIX es va generalitzar el que la teoria dels polisistemes defineix com a «repertori» (EvenZohar, 1999: 31 i següents), açò és, una selecció d'obres, autors, etc., sobre els quals es fonamenta un patrimoni cultural entés com un referent identitari on conflueixen els paràmetres lingüístics, literaris, culturals i socials. El centre d'aquest sistema l'ocupen els productes definits com a canònics, mentre que en la perifèria apareixen els que, per una raó o una altra, no responen als criteris dominants. Com assenyala Lluch (2003: 193), aquests repertoris s'han establit «en función de unos parámetros a veces tan subjetivos sobre la calidad estética o la originalidad. O ciertos inconfesables elitismos de clase que han situado fuera determinadas manifestaciones paraliterarias».

Al seu torn, Bourdieu (1987: 156), mitjançant la seua noció d'habitus, determina els vincles entre el repertori com a institució social i els procediments d'interiorització individual dels valors transmesos per un discurs legitimador de les estructures dominants, que actuen com a referents de conductes assimilades pel sistema social.

A partir d'aquests paràmetres, cal qüestionar-se quin ha sigut el paper dels manuals d'història literària en la reproducció i transmissió d'un model de repertori, que ha canalitzat cap a les programacions les indicacions generals dels currículums entorn del tema -bastant genèriques, encara que es mencionen obres i autors, i amb un marge notable per a la implementació-, a través d'interpretacions amb escasses variants entre ells, més enllà de les incorporacions d'innovacions relacionades amb les TIC. Es confirma, així, la crítica de Martínez Bonafé (2008: 68) sobre la incidència d'aquestes obres en la pràctica 
de l'activitat docent: «el libro de texto es una herramienta ya pensada, una herramienta de trabajo - un medio de producción cultural- separado de los productores y de los procesos de producción cultural».

Aquesta qüestió resulta més rellevant si es contrasta amb les demandes dels corrents actuals en didàctica de la literatura, centrats en la configuració d'un cànon literari escolar de caràcter dinàmic, «es decir, con cierta capacidad para modificarse cada cierto tiempo» (Cerrillo, 2013: 26).

Però no s'esgota ací el tema, perquè si bé és cert el que s'ha exposat sobre els manuals - constrets per factors tan determinants com són les imposicions gremials, institucionals, de tradicions arrelades en la pràctica docent, la competència entre editorials pel mercat-, no és menys cert que també ha d'avaluar-se la mediació professional dels docents.

Des de la concepció de Giraux (1990) del professor com a «intel-lectual transformador», que reflexiona i intervé en el currículum per a adequar-lo a les necessitats d'aprenentatge i per a convertir-lo en un instrument capaç d'impulsar dinàmiques transformadores, el llibre de text ha passat a ser jutjat en els termes que proposa Gimeno Sacristán (1988: 185):

La competencia profesional de desarrollar el currículum, en principio una de las atribuciones genuinas del profesor, la comparten cuando no la monopolizan los mecanismos de prodcción de materiales que hay detrás de un número reducido de firmas comerciales.

En aquesta tessitura, habitual en l'activitat docent, el manual es converteix en la concreció última del currículum, legitimada per l'administració, que reprodueix un currículum ocult el desenvolupament del qual depén de la seua aplicació per part del professorat. En el camp concret de la història literària, la veritat és que actua com a guia de la pràctica docent, amb un pes més evident que en la resta de blocs de la matèria, com continguts desvinculats de la programació integrada de destreses lingüístiques, i pròxims a un eix historiogràfic on se situen els temes seguint un model de successió temporal.

Enfront d'això, la veritat és que la història de la literatura constitueix un espai d'intervenció didàctica en què es poden ampliar metodologies d'aprenentatge innovadores, basades en algunes de les aportacions comentades amb anterioritat. Així ho indica Mendoza Fillola (1998: 265) en la seua apreciació general sobre l'activitat del professor de llengua i literatura:

Opinamos que, más que enseñar muchos conocimientos (dispares o de tipo prescriptivo o normativo), se trata de construir saberes pragmáticos, operativos, esto es, de enseñarlos a utilizar inteligentemente para construir una metodología cercana a la realidad de los alumnos, quienes pueden interesarse menos por la reflexión especulativa que por los problemas concretos del uso de la lengua o por la comprensión de un determinado texto.

En la seua proposta, l'autor (1998: 252) determina que en el segon nivell de concreció de tot procés de programació - el de la «pragmatització/contextualització» del marc epistemologicocurricular-, és el professor el que ha d'actuar en els nivells següents:

- Selecció i concreció de continguts. 
- Revisió, anàlisi i valoració de continguts i suggeriments estratègics d’intervenció didàctica.

- Valoració formativa d'aquests.

- Compensar les necessitats d'actualització epistemològica de l'àrea.

- Concreció de continguts curriculars.

- Comprendre que els currículums oficials són descriptius i orientatius.

- Adoptar una actitud crítica davant les formulacions curriculars.

- Entendre i relacionar els tres tipus de continguts propis de l'àrea.

En aquesta projecció, el llibre de text — seleccionat per una decisió departamental en què haurien d'haver primat els criteris epistemològics relacionats amb els objectius d'aprenentatge - aporta una interpretació completa i tancada, que si s'adopta com a única referència de l'acció didàctica i no és sotmesa a una revisió crítica i adequada en la realitat de l'aula, constitueix un sistema únic d'aprenentatge que transmet no sols un model de continguts, sinó d'enfocaments metodològics.

El present treball analitza el tractament de la literatura medieval i del Segle d'Or per part dels llibres de text, per a la qual cosa incideix en qüestions que afecten l'orientació sexista dels seus plantejaments, no sols a través dels continguts presentats, sinó dels criteris de selecció que apunten al desequilibri entre personatges masculins i femenins, a la funció de la dona com a subjecte literari i com a destinatari del fenomen literari. En definitiva, es proposa una anàlisi crítica de situacions discriminatòries que perviuen, transmeses per la cultura literària si aquesta és observada des d'una perspectiva estrictament descriptiva i no analiticoexplicativa.

\section{La dona subjecte literari i destinatària}

Un dels espais d'intervenció didàctica més rellevants en la història de la literatura és el que té com a objectiu una programació que propose una mirada equilibrada pel que fa a la presència d'homes i de dones en el domini de la ficció literària, més enllà de qüestions d'índole temàtica i, per descomptat, de l'autoria, com ja s'ha dit.

En la literatura medieval poden desplegar-se projectes didàctics relacionats tant amb el subjecte literari, la veu que des de l'enunciat projecta un determinat punt de vista sobre els fets, com des de la perspectiva del destinatari, és a dir, l'estança de recepció, l'horitzó d'expectatives de la qual condiciona no sols l'orientació temàtica sinó, fins i tot, l'existència d'un determinat discurs literari.

El primer dels aspectes comentats — el del subjecte que defineix l'enfocament de la ficció des de l'organització dels discursos com a construccions socials que responen a modalitats cognitives de pensar la realitat, on es materialitza l'habitus de Bourdieupermet una anàlisi de les pràctiques literàries medievals des de la qual és factible programar unitats didàctiques alternatives als usos tradicionals.

Els dos fenòmens literaris privilegiats en l'aula han sigut el de l'èpica i el del vessant culte, que engloba tant el mester de clerecia com, posteriorment, la lírica de cançoner i la gradual irrupció del petrarquisme.

Enfront d'aquests dos, hi ha un tercer corrent, el de la lírica popular, que permet projectar sobre la programació d'aula una modalitat literària diferent dels dos referents habituals: 
- Davant del tema bèl-lic i la inspiració heroica dominant en les cançons de gesta, les jarches, les nadales i les cantigues tracten el tema amorós des del punt de vista d'un subjecte líric jove i femení.

- Aquesta condició apuntada del subjecte líric no guarda relació amb la tradició de l'amor cortès, en el qual la dona és receptora passiva de rituals amorosos molt codificats. Enfront d'això, en els esmentats gèneres - en diverses llengües, la qual cosa resulta molt rellevant en la formació multicultural- l'expressió sorgeix a partir d'una inspiració popular, en la que té cabuda el simbolisme, l'emotivitat sincera per l'absència de l'estimat, des de la perspectiva d'una jove que proclama els seus sentiments en el marc de la naturalesa i de la sensualitat.

Aquestes característiques converteixen aquesta tradició en un model idoni per a programar seqüències didàctiques capaces de connectar amb les expectatives d'un receptor adolescent, amb la preeminència d'una visió femenina en contrast amb els formats masculins de la resta de gèneres medievals. Si, a més, com s'exposa en els apartats anteriors, s'adopta una perspectiva tematològica, allunyada de l'excés historicista, la poètica popular permet establir una línia de continuittat, en temes i formes, no sols amb els poetes del Segle d'Or, sinó amb nombrosos escriptors contemporanis (per exemple, del 27, com ara Lorca i Alberti) i, fins i tot, amb discursos actuals — de l'àmbit musical, per citar-ne un - que incorporen l'immens llegat d'aquesta tradició (vocabulari, metàfores, símbols, orientació sentimental, perspectiva femenina, etc.).

\begin{tabular}{|c|c|c|c|c|c|c|c|c|c|c|c|c|c|}
\hline \multirow[t]{2}{*}{ Editorial } & \multicolumn{2}{|c|}{$\begin{array}{l}\text { Presència } \\
\text { lírica popular }\end{array}$} & \multicolumn{2}{|c|}{$\begin{array}{l}\text { Teoria sobre } \\
\text { subjecte líric }\end{array}$} & \multicolumn{3}{|c|}{$\begin{array}{l}\text { Extensió respecte d'altres } \\
\text { gèneres }\end{array}$} & \multicolumn{2}{|c|}{$\begin{array}{l}\text { Exercicis sobre } \\
\text { lírica popular }\end{array}$} & \multicolumn{2}{|c|}{$\begin{array}{l}\text { Exercicis sobre } \\
\text { subjecte líric }\end{array}$} & \multicolumn{2}{|c|}{$\begin{array}{l}\text { Activitats } \\
\text { complementàries }\end{array}$} \\
\hline & Sí & No & Sí & No & - & igual & + & Sí & No & Sí & No & Sí & No \\
\hline Anaya & $x$ & & $\mathrm{x}$ & & $\mathrm{x}$ & & & $x$ & & $\mathrm{x}$ & & & $\mathrm{x}$ \\
\hline Edebé & $x$ & & $\mathrm{x}$ & & $x$ & & & & $\mathrm{x}$ & & $\mathrm{x}$ & & $\mathrm{x}$ \\
\hline McGraw Hill & $\mathrm{X}$ & & $\mathrm{x}$ & & & $\mathrm{x}$ & & $x$ & & $\mathrm{x}$ & & $\mathrm{x}$ & \\
\hline Santillana & $x$ & & & $\mathrm{x}$ & $\mathrm{x}$ & & & & $\mathrm{x}$ & & $x$ & & $\mathrm{x}$ \\
\hline Sansy & $x$ & & $\mathrm{x}$ & & $\mathrm{x}$ & & & $x$ & & $\mathrm{x}$ & & & $\mathrm{x}$ \\
\hline Micomicona & $x$ & & & $\mathrm{x}$ & $\mathrm{x}$ & & & $x$ & & & $\mathrm{x}$ & & $\mathrm{x}$ \\
\hline \multicolumn{14}{|l|}{ Vicens Vives } \\
\hline Oxford & $x$ & & $\mathrm{X}$ & & & & $\mathrm{x}$ & $x$ & & $\mathrm{x}$ & & $\mathrm{x}$ & \\
\hline SM & $\mathrm{X}$ & & $\mathrm{x}$ & & $\mathrm{x}$ & & & $x$ & & $x$ & & & $\mathrm{x}$ \\
\hline Bruño & & $\mathrm{x}$ & & $x$ & $\mathrm{x}$ & & & & $\mathrm{x}$ & & $X$ & & $\mathrm{x}$ \\
\hline ECIR & $\mathrm{x}$ & & $\mathrm{x}$ & & & $\mathrm{x}$ & & $x$ & & $\mathrm{x}$ & & & $\mathrm{x}$ \\
\hline Edelvives & $x$ & & $x$ & & $\mathrm{x}$ & & & & $\mathrm{x}$ & & $x$ & & $x$ \\
\hline
\end{tabular}

Taula 1: Tractament de la lírica popular en els llibres de text.

En la taula 1, es poden observar les dades quantitatives pel que fa al tractament de la lírica popular en els llibres de text, com a reflex no sols de l'interés que desperta aquest gènere en els manuals respecte d'altres discursos, sinó, sobretot, del potencial per a treballar en l'aula uns textos que situen la dona com a eix de l'expressió literària enfront del domini de la perspectiva masculina en l'èpica i en la poesia cortesana. 
Les dues primeres columnes mostren un panorama semblant pel que fa a la presència de la lírica popular, excepte les editorials que no tracten la literatura medieval i el de Bruño, que circumscriu la seua descripció de la literatura popular al romancer.

A partir de la tercera columna, pot apreciar-se com les editorials revelen una tendència molt consolidada en la pràctica docent de $3 \mathrm{r}$ d'ESO: un gènere amb notables possibilitats innovadores en el terreny de la programació, presenta una extensió sensiblement inferior en relació amb les cançons de gesta, la qual cosa és simptomàtica sobre cap a on es dirigeix l'interés didàctic en aquest aspecte.

Un cas paradigmàtic és el de l'editorial Sansy, perquè en el contrast entre el tema 1 -dedicat a la lírica popular-i els temes 2 i 3 -dedicats a l'èpica i a la prosa medieval, respectivament - , s'observa la diferència de tractament en la programació de les unitats: en el primer cas, el bloc literari es presenta al marge dels referits a matèries lingüístiques; en els altres dos, en canvi, s'ofereix una programació integrada, amb una visió horitzontal de l'organització dels continguts, segons el model de l'enfocament comunicatiu. El tractament didàctic dels temes evidencia la primacia en l'orientació del plantejament docent.

Una cosa semblant pot dir-se respecte les pràctiques guiades sobre el tema (columnes 4, 5 i 6): si hi ha uniformitat en les dues primeres columnes, no passa així en aquestes tres, en les quals es comprova que, enfront de l'extensió d'exercicis sobre altres gèneres, algunes editorials transmeten la imatge d'escassa entitat de la poesia popular en presentar-la com un simple apartat teòric sense desenvolupament posterior en exercicis de lectura.

Pel que fa al segon referent femení susceptible d'un tractament innovador en l'aula, el del destinatari, cal recordar que, a partir del segle xv, després de la implantació generalitzada de la impremta i els canvis sociològics en l'àmbit urbà, sorgeix amb força el fenomen del públic lector, la qual cosa constitueix el germen social sobre el qual es va a desenvolupar un nou gènere: la novella.

Aquest fet transcendental, ignorat en la majoria de manuals a pesar que personatges com ara el Quixot o el llicenciat Vidriera permetrien endinsar-se en les addiccions actuals dels adolescents - com les del món digital-, té, a més, una dimensió femenina, ja que les dones van ser el sector de lectors que van condicionar fins $i$ tot algun dels gèneres narratius més rellevants. N'hi ha prou a recordar la formació de Melibea respecte d'això -un altre dels vessants susceptibles de ser integrats en una programació com la descrita-, o la novel-la sentimental i la bizantina, dos models literaris de notable èxit durant els segles XV i XVI, que tindran la seua continuació en la proposta renovadora de Cervantes, i que en gran mesura van ser creats per a un receptor femení.

Aquest aspecte és obviat per la majoria dels manuals. De fet, són molt escasses les al-lusions a la novellla del segle xv (la prosa medieval sol concloure amb Juan Manuel): el d'Anaya parla de la novellla de cavalleria, el de McGraw Hill, a més, de la novel·la sentimental; el de Bruño, de la novella artúrica i la de cavalleria.

El llibre d'SM és el que més espai dedica al tema, perquè reserva sis pàgines per al prerenaixement, en les quals presenta els gèneres narratius $i$, fins $i$ tot, proposa un exercici amb un text de la Cárcel de amor de Diego de San Pedro, del qual es desprén la rellevància del destinatari femení en aquest tipus d'obres. També el d'Edelvives tracta els diferents gèneres narratius, encara que sense lectures ni activitats. 


\section{Els personatges femenins}

El tractament dels personatges és un altre dels símptomes per a detectar el currículum ocult dels manuals quant a les possibilitats que ofereixen respecte a la programació d'activitats centrades en la preeminència del component femení i les seues implicacions en tasques l'objectiu de les quals siga equilibrar les perspectives sexistes.

En aquest cas, l'estudi se centra en dos personatges femenins molt rellevants en l'època objecte d'estudi: Melibea i la pastora Marcela del Quixot. En el primer dels casos, no interessa la seua presència en els manuals - atès que és un dels protagonistes, és obligatòria-, sinó l'enfocament didàctic sobre ella; en el de la jove a qui es responsabilitza de la mort de Crisóstomo, en el capítol XII de la primera part de l'obra cervantina, l'interés rau en si es menciona el seu suggestiu discurs reivindicatiu de la llibertat de la dona en l'elenc de personatges mencionats.

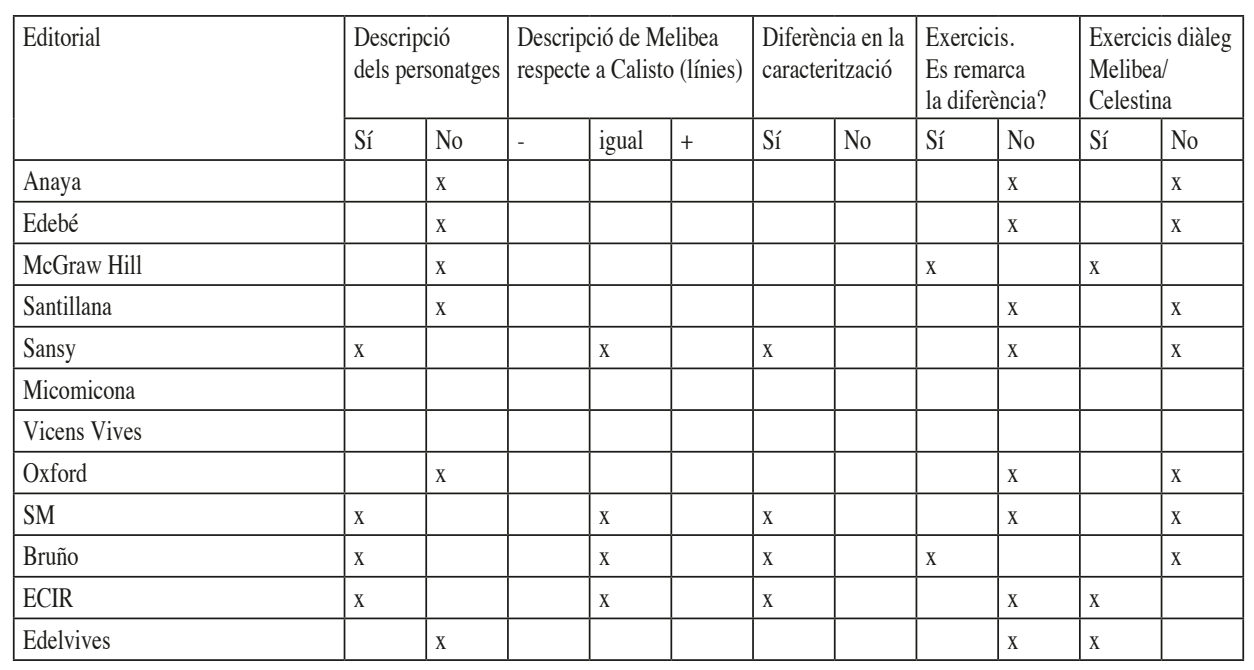

Taula 2: Caracterització de Melibea en els llibres de text.

Com es pot observar en la taula 2, els àmbits d'estudi sobre Melibea són els següents:

- Al marge de Celestina, Melibea és el personatge més complex de l'obra, amb una caracterització que mostra un nou model femení en la literatura: una jove instruïda, amb afició per la lectura - en el context del nou públic literari comentat en l'apartat anterior-, d'extrema sensibilitat i amb una projecció de la relació amorosa que va més enllà de la imatge de la dona en la tradició de l'amor cortès.

Així, a pesar que funcionalment se situa en el mateix nivell actuacional que Calisto, les seues paraules, els seus silencis, la seua actuació, en definitiva, la converteixen en la representació d'un ésser d'enorme interés humà enfront del seu pretendent, un esvalotat i impulsiu a qui Bataillon (1961) no va dubtar a qualificar «d'obsès ridícul». Les seues respectives reaccions en la relació 
amorosa, descrites en l'acte XII -al qual l'Editorial Bruño li concedeix singular importància-, defineixen les seues diferències, de manera que Melibea es mostra com un personatge amb possibilitats per a desenvolupar activitats didàctiques que evidencien el contrast entre ambdós.

- Aquesta diferència en la caracterització, que singularitza Melibea enfront del seu amant, es pot testimoniar a través de diversos episodis de l'obra: les converses entre ambdós i, sobretot, el magistral diàleg de la jove amb Celestina, els persuasius dots de la qual estan a punt de fracassar, la qual cosa revela la forta determinació i la profunditat del caràcter de Melibea a diferència, per exemple, de la relativa facilitat amb què l'alcavota convenç Pármeno en un procés argumentatiu semblant.

Aquests han sigut els paràmetres estudiats en les diverses editorials a fi de dilucidar si entre els continguts i les activitats presentades en els manuals s'albira el desequilibri caracteriològic en favor del personatge femení.

En primer lloc, segons manifesten les dades de la taula 2, resulta simptomàtic que només quatre editorials presenten una descripció dels personatges, més enllà d'allò estrictament funcional en l'exposició de l'argument, perquè desvela un reduccionisme dels continguts literaris, limitats a la mera acció, la qual cosa resulta empobridora en obres clàssiques de l'envergadura de La Celestina, en què la trama s'inscriu en una tradició consolidada d'embolics amorosos, i en la qual són els personatges els que li atorguen la seua singularitat.

Encara que en quatre editorials s'exposen les diferències entre els protagonistes, i s'insisteix en la major complexitat del personatge femení, en cap se li dedica més atenció, la qual cosa en la pràctica suposa presentar-los com a personatges semblants, per la qual cosa s'assumeix com a criteri únicament el funcional enfront del més complet i significatiu que és el d'índole semàntica, fet que permetria situar Melibea en un rang superior, amb totes les conseqüències didàctiques que es desprendrien d'aquest fet.

Tampoc en el terreny dels exercicis s'observa una perspectiva que focalitze l'interés sobre la dama enfront del seu amant, i això a pesar que en la trobada amorosa de l'acte XII, s'ofereix un testimoni de les diferents actituds amb què afronten el fet: l'impuls irracional, violent, quasi animal de Calisto, enfront de la maduresa amb què la jove experimenta la sexualitat. Només dues editorials es detenen en aquesta seqüència.

Quelcom semblant succeeix amb l'esmentat diàleg de Celestina i Melibea, un portentós discurs persuasiu, revelador de dos caràcters amb forta determinació de les dues personalitats més intenses de l'obra. Tres editorials li dediquen la seua atenció, en contrast amb la centrada en la conversa inicial entre els dos protagonistes, que continua sent el més habitual en els manuals.

El cas de la pastora Marcela i el seu discurs de reivindicació feminista davant del cadàver de Crisóstomo - capítol XII de la primera part del Quixot- planteja el tema del currículum ocult a partir dels criteris de selecció a l'hora de programar seqüències didàctiques des de l'òptica del gènere en la historiografia literària.

Com ja s'ha anticipat en un altre apartat, enfront de l'opció d'estudiar escriptores, resulta més operatiu, si es pretén adoptar una postura d'equilibri en el tractament sexista, el tractament d'aspectes relacionats amb les mateixes obres literàries quan, com en aquest 
cas, hi ha la possibilitat d'accedir a discursos reivindicatius des dels quals es poden oferir múltiples activitats centrades fins i tot en la tradició literària (el paper de la dama en l'amor cortès, la figura de la dama en les èglogues pastorals, etc.). Es tracta d'adoptar un punt de vista, la figura de la dona, per exemple, a partir d'una manifestació de primer nivell, i des d'ací proposar un recorregut pels principals models de la literatura de l'època. Si, a més, es pretén incorporar al procés didàctic el treball sobre valors de manera explícita, el discurs de Marcela davant de les crítiques dels amics del seu infortunat pretendent constitueix un referent amb notables implicacions per a la programació.

Resulta evident que una obra com el Quixot és molt enriquidora des de la dimensió didàctica, sobretot si l'enfocament supera els límits de la mera erudició per a afrontar reptes més ajustats a objectius comunicatius, vinculats amb la creativitat, la transversalitat, l'anàlisi del discurs, la tematologia, la formació en valors i altres dimensions que situen l'educació literària en el domini d'una pedagogia de l'empoderament, emancipadora i alternativa a la mera transmissió de continguts.

En aquesta línia, els manuals analitzats tendeixen a oferir un llistat de personatges —només en el d'Edebé se cita Marcela-, d'aventures, amb un plantejament pròxim a l'acumulació de dades, en els quals la presència masculina és omnipresent, fins al punt que el de l'Editorial Bruño afirma el següent: «Cervantes es el primer creador de personajes modernos [...] hombres [la cursiva és meua] comunes que cambian conforme a sus experiencias».

\section{La dona, subjecte social: misogínia i lleis de l'honor}

Enfront de les tendències estrictament historicistes entorn de l'ensenyamentaprenentatge de la literatura en els cursos superiors de l'ESO, vinculades amb models didàctics l'eix dels quals és l'acció exclusiva del professor com a transmissor de dades, els corrents actuals proposen una concepció de la literatura en l'aula que contribuïsca a la formació integral de l'alumnat, tal com indica Colomer (2001: 10):

El objetivo de la educación literaria, en primer lugar, es el de contribuir a la formación de la persona, formación indisolublemente ligada a la construcción de la sociabilidad y realizada a través de la confrontación con textos que explicitan la forma en que las generaciones anteriores y los contemporáneos han abordado y abordan la valoración de la actividad humana a través del lenguaje.

Es tracta d'una «concepción de la literatura que la convierte en motivo para el crecimiento personal y el cambio de la sociedad, así como para la elaboración de un juicio crítico y una palabra propia» (Regueiro, 2014: 385). I això des de la convicció que, com señala Fernández Soto (2011: 92):

los textos literarios están repletos de enseñanzas para la vida que son perfectamente utilizables en el aula con los alumnos. En ellos encontrarán situaciones cotidianas o fantásticas, pero que adaptándolas al contexto actual podrán aplicarse para generar modelos positivos de comportamiento. 
L'aplicació d'aquests principis a l'activitat didàctica suposa afrontar l'ensenyament de la història de la literatura no sols contextualitzant les obres del passat, sinó, el que és més rellevant en la formació del judici crític de l'alumnat, determinant les motivacions culturals que expliquen l'existència de determinades pràctiques literàries i artístiques, en la mesura que moltes d'aquestes continuen presents en l'actualitat, amb la qual cosa la literatura es converteix en una font privilegiada per a traslladar a l'aula situacions socials conflictives $i$, en aquest cas, sobre conductes sexistes.

Aquest és el cas de dues línies temàtiques que recorren diferents èpoques del passat literari per la seua presència constant en obres de tota índole: la misogínia i el lloc de la dona en l'àmbit familiar.

Pel que fa a la misogínia, aquest és, sens dubte, un dels corrents temàtics fonamentals en la literatura medieval - i, fins i tot, renaixentista-, present en tot tipus de gèneres, encara que de manera destacada en la rondallística de tradició oriental i, per això, en Juan Manuel, per citar un autor de referència en els manuals. Però, és el Libro de buen amor l'obra en què millor s'observa aquest vessant cultural. A pesar de la seua complexitat i de la impossibilitat de reduir-la a esquemes simplistes d'interpretació, resulta evident que una de les dimensions més clares del llibre respon a aquesta visió crítica de la dona.

La misogínia té diversos orígens, fins i tot en els clàssics grecollatins, però, com recorda Escartín (2007-2008), les arrels religioses judeocristianes en són les més significatives, amb figuracions tan impactants com les recollides en el Gènesi:

La literatura de la época reflejó la relación entre Eva - culpable de introducir el pecado en el mundo - y la serpiente demonio, símbolo de la tentación y del mal (60).

Aquesta relació entre el component religiós i el menyspreu a la dona, pròpia d'algunes cultures com l'occidental, continua vigent en diferents vessants: el paper de la dona en el mercat laboral, la seua condició familiar, la centralitat de la visió de l'home en els plantejaments socials, fins arribar-hi a episodis de violència com a expressió extrema.

En aquesta línia, l'estudi de la literatura antiga pot ser un espai idoni per a treballar en l'aula qüestions com ara la identificació del problema, el seu origen, les causes encara vigents, les formes en què es manifesta, el contrast entre èpoques, les noves formes de marginar la dona, etc. Per això, si el llibre de text continua exercint de guia didàctica en aquesta àrea de coneixement, ha de contemplar el problema i plantejar-lo a l'alumnat que el segueix com a referència.

En cap dels manuals consultats apareix la misogínia com un dels temes rellevants de la cultura i de la literatura medievals, i això a pesar que els d'algunes editorials - Anaya, Oxford, ECIR - dediquen un espai considerable a desenvolupar el context de l'època. S'insisteix molt en la qüestió social i fins i tot en la presència del discurs religiós com articulador del pensament medieval; però, no obstant això, no es planteja la situació de la dona com un dels grans tòpics artístics del moment ni, per descomptat, els orígens d'aquesta actitud.

Més sorprenent és el silenci entorn del Libro del buen amor -com l'obra més representativa d'aquesta tendència -, ni tan sols en aquells manuals com els de SM i Anaya que despleguen en extensió, tant en teoria com en activitats, el llibre de Juan Ruiz. 
L'aproximació més interessant al tema de la misogínia apareix en el manual de l'editorial Sansy, quan s'indica que l'objectiu de l'obra és «enseñar el buen amor (de Dios) mediante el ejemplo del amor errado (de la mujer)». Es limita, doncs, a un simple esbós expositiu sense proposar una explicació, la qual cosa contribueix a generar una carència en el comentari de les claus que podrien generar un espai d'intervenció suggestiu, no sols per a la comprensió del fenomen, sinó per a la seua aplicació en projectes didàctics diversos.

Quelcom semblant succeeix en el segon dels motius analitzats: la posició ocupada per la dona en l'organització familiar a través d'un dels temes més habituals en el passat, el de l'honor i l'honra.

La concepció de la família, en la qual la filla és una mera funció instrumental vinculada amb el pare, respon a una visió patriarcal per la qual els actes individuals femenins repercuteixen en el conjunt de la família i, per tant, en la imatge pública del pare com a representant de la cèl-lula social.

Resulta evident que l'esmentada caracterització familiar s'ajusta a un model que s'ha perpetuat i, amb lleugeres variacions, ha arribat fins l'actualitat. Les adolescents experimenten, en l'etapa que ens ocupa, diferents graus d'imposició moral que corresponen a una perspectiva de les relacions familiars sotmesa al referent patern.

La literatura de l'antiguitat ofereix testimonis d'aquesta realitat almenys en dos instants simptomàtics: el Cantar del Mío Cid i el teatre barroc.

En el primer dels casos, l'episodi de la roureda de Corpes, on els infants de Carrión es vengen del Cid a través de les seues filles, és un exemple del tema proposat.

Tots els manuals ofereixen informació sobre la denominada afrenta de Corpes, però en tots ells es presenta en clau de l'heroi - resposta dels infants a les humiliacions patides-, sense que això supose una lectura que explique el comportament dels personatges en clau d'una organització familiar que redueix les joves a un paper funcional, sense cap mena de personalitat en si mateixes. El relat simplificat en el desenvolupament argumental planteja com a lògica, en una visió casuística, l'acció sobre les dones sense que d'això es desprenga una explicació valorativa. Es presenta, així, com normal un tipus de relació en el qual l'eix interpretatiu no és la víctima immediata, sinó el nucli familiar representat, en aquest cas, pel Cid:

Las hijas del Cid son maltratadas y abandonadas por sus maridos. El Cid recupera su honor con la segunda boda de sus hijas con otros nobles (SM, 94).

Los infantes maltratan a las hijas del Cid en el robledal de Corpes. El Cid repara esta nueva pérdida de su honra y concierta nuevas bodas para sus hijas con los infantes de Navarra y Aragón (Mc Graw Hill, 135).

Ofendidos [los infantes de Carrión], maltratan y abandonan en Corpes a las hijas del Cid, quien pide justicia ante el Rey. Los infantes son castigados y el Cid cobra mayor prestigio al casar a sus hijas con los príncipes de Navarra y Aragón (ECIR, 114).

La literatura posterior, concretament el teatre del Segle d'Or, va desenvolupar aquest tòpic com un dels principals motius dramàtics de la comèdia nova. L'honor i l'honra són el fonament argumental sobre el qual es construeix la trama tant de les obres de caràcter més tràgic com de les comèdies urbanes 'de enredo'. 
Com succeïa en el cas del Mio Cid, la dama en el teatre de Lope és el vèrtex sobre el qual convergeix l'honra familiar, el dipositari, i per això guardià, de la qual és la figura masculina, siga el pare, siga el germà.

La imatge patriarcal de la família sobre la qual posa els fonaments el tema de l'honor no troba cabuda en els manuals. En tots s'insisteix en el lloc destacat d'aquest concepte en el model literari imperant, però no en els fonaments ideològics i socials sobre els quals se sustenta. I això a pesar que les obres de Lope de Vega més estudiades -Peribáñez y el Comendador de Ocaña i Fuenteovejuna - i la de Caledrón -El Alcalde de Zalameapresenten un ultratge violent de la dama. En l'explicació, s'opta per la qüestió social -el conflicte entre el poderós i la vilatana-, i a penes es refereix el fet que el conjunt de la trama es vertebra des de la constatació que la violència deslliga la resposta lògica del pare.

En alguns dels manuals analitzats s'exposa la situació creada a partir de l'organització familiar comentada, encara que, com succeïa en el cas de les cançons de gesta, sense esmentar els aspectes discriminatoris que es manifesten:

La mujer es la depositaria del honor familiar y el padre o el hermano los encargados de defenderlo. Si una mujer perdía su honor había dos soluciones posibles: el matrimonio o la muerte del seductor (Edelvives, 125).

Como son los demás los que dan o quitan la honra, uno ha de vigilar que no haya mancha alguna en la familia (ECIR, 215).

\section{Conclusió}

Els llibres de text, la vigència dels quals en la pràctica docent ha sigut constatada per diferents estudis, condiciona no sols la metodologia didàctica, sinó també el model formatiu que es transmet a partir d'una eina de treball que el docent assumeix i, amb això, tot el procés de programació i de reflexió, que passa a estar externalitzat i en mans d'una empresa editorial. A més, l'esmentat model exposa els continguts a partir d'uns supòsits implícits, el currículum ocult, que entren a formar part del trajecte formatiu.

En el cas concret del bloc dedicat a la història de la literatura en 3r d'ESO — primer curs en què s'estudia la dita matèria-, la situació descrita s'aguditza perquè la dependència del manual sol ser més determinant que, per exemple, en els blocs dedicats a la llengua i al discurs, amb una tendència molt marcada cap a una didàctica basada en l'erudició i en una historiografia centrada en la classe magistral i en la mera transmissió de dades.

Enfront dels corrents actuals de didàctica de la literatura, que advoquen per un ensenyament de la literatura lligat a la construcció del pensament crític i social, la presència dominant dels manuals impedeix una visió més oberta i comunicativa de la història de la literatura, que fomente la creativitat i la capacitat associativa de l'alumnat a partir de les propostes tematològiques, de la literatura comparada, de la transversalitat, de les programacions integrades, etc.

Des d'aquesta opció alternativa, cal reivindicar un aprenentatge significatiu de la història literària que sintonitze amb els objectius generals d'una educació dirigida a fomentar l'autonomia personal a través del coneixement i valoració de les activitats humanes. En aquesta línia, l'estudi de la literatura del passat pot aportar notables referents sempre que s'aborde des d'una disposició explicativa que permeta establir vincles entre l'antiguitat i l'entorn de l'estudiant. 
Com s'ha observat en l'anàlisi de les pàgines anteriors, els llibres de text actuals, a pesar que han actualitzat, en molts casos, les seues activitats, fins i tot amb tallers d'indubtable interés formatiu, han generalitzat una inèrcia en la descripció de la història de la literatura per la qual s'ha arribat a una extensió quantitativa de pàgines de teoria $\mathrm{i}$ d'exercicis sobre textos, però no a un canvi qualitatiu que promoga una selecció diferent de temes i d'orientacions per a tractar les qüestions implicades en una educació emancipadora, la que ajuda a comprendre els perquès, a plantejar opcions noves i a relativitzar els valors dominants.

\section{BIBLIOGRAFIA}

Apple, M.W. (1989): Maestros y textos, Barcelona, Paidós/MEC.

Bataillon, M. (1961): La Célestine selon Fernando de Rojas, París, Librairie Marcel Didier.

Bourdieu, P. (1987): Choses dites, París, Minuit.

Cerrillo, P.C. (2013): «Canon literario, canon escolar y canon oculto», Quaderns de Filologia. Estudis literaris, XVIII, 17-31.

Colomer, T. (1996): «La didáctica de la literatura: temas y líneas de investigación e innovación», dins LomAs, C. (coord.): La educación lingüística y literaria en la enseñanza secundaria, Barcelona, Horson-Universitat de Barcelona, 123-142.

- (2001): «La enseñanza de la literatura como construcción de sentido», Lectura y vida, diciembre, $1,6-23$,

Even-Zohar, I. (1999): «Factores y dependencias en la cultura. Una revisión de la teoría de los Polisistemas», dins Iglesias, M. (comp.): Teoría de los Polisistemas, Madrid, Arco Libros, 23-51.

EsCARTín, M. (2007-2008): «Pandora y Eva:la misoginia judeo-cristiana y griega en la literatura medieval y española», Revista de literaturas catalana, gallega y vasca, XIII, 55-71.

FERnÁNDEZ, L. (2011): «Desarrollo de valores a través de la lectura de las grandes obras de la literatura universal», Cálamo, 58, 91-97.

Gimeno, J. (1988): El currículum. Una reflexión sobre la práctica, Madrid, Morata.

GiRaux, H. (1990): Los profesores como intelectuales. Hacia una pedagogía crítica del aprendizaje, Barcelona, Paidós.

Lluch, G. (2003): Análisis de narrativas infantiles y juveniles, Cuenca, Ediciones de la Universidad de Castilla- La Mancha

LóPEZ-Navajas, A. (2014): «Análisis de la ausencia de las mujeres en los manuales de la ESO: una genealogía del conocimiento ocultada», Revista de Educación, 363. DOI: 10.4438/1988-592X-RE2012-363-188. Consulta realizada el 6 de julio de 2016.

LóPEZ-NAVAJAS, A. I M. QueRL (2014): «Las escritoras ausentes en los manuales: propuestas para su inclusión», Didáctica. Lengua y Literatura, 26, 217-240.

Martínez, J. (2008): «Los libros de texto como prácticas discursivas», Revista de la Asociación de Sociología de la Educación, 1, 1, 62-73.

Mendoza, A. (1998): «Marco para una didáctica de la Lengua y la Literatura en la formación de profesores», Didáctica, 10, 233-269.

- (2011): «La formación receptora: análisis de los componentes del intertexto lector», Tarbiya, 41, 53-69.

Pozuelo, J.M. (1996): «Canon: ¿estética o pedagogía?», Ínsula, 600, 3-4.

RegueIro, B. (2014): «Innovación y creatividad: enseñar literatura en el siglo XXI», Humanidades digitales, Anexo I, 383-393.

SAlvador, V. (2000): Poesia, ciutat oberta. Incursions en el discurs poètic contemporani, València, Tàndem.

Santos, M.Á. (1997): «Currículum oculto y construcción del género en la escuela», Kikirikí, 42-43, 14-27. Yus, R. (1997): Hacia una educación global desde la transversalidad, Madrid, Alauda-Anaya. 


\section{Manuals analitzats}

(Tots els manuals corresponen al nivell de $3 \mathrm{r}$ ESO) BleCUA J.M. (coord.) (2015): Lengua Castellana y Literatura, Madrid, SM.

Burraco, R. i altres (2015): Lengua Castellana y Literatura, Saragossa, Edelvives.

Escribano, E. i P. Rodríguez (2015): Lengua Castellana y Literatura, Barcelona, Vicens Vives.

Gómez, J. i altres (2015): Lengua y Literatura, Madrid, Bruño.

GonZÁLez, J.M. i altres (2015): Lengua Castellana y Literatura, Madrid, Oxford.

Grence, T. (coord.) (2015): Lengua y Literatura. Serie Libro abierto, Madrid, Santillana.

GutiérRez, S. i altres (2015): Lengua y Literatura, Madrid, Anaya.

Mínguez, A. i J.L. Moliner (2011): Lengua Castellana y Literatura, Paterna, ECIR.

Nogales, N. i altres (2015): Lengua y Literatura, Barcelona, Edebé.

Pantoja, J.C. i altres (2015): Lengua Castellana y Literatura, Madrid, Mc Graw Hill.

Ricós, A. (coord.) (2015): Lengua Castellana y Literatura. Proyecto Argos, València, Sansy Ediciones.

RiQuelme, J. (coord.) (2015): Lengua Castellana y Literatura, València, Micomicona.

\section{BIONOTA}

Javier Vellón Lahoz, professor titular d'universitat, adscrit al departament de Filologia i Cultures Europees de la Universitat Jaume I. La seua trajectòria investigadora es relaciona amb diferents vessants vinculades amb grups d'investigació i amb la seua tasca docent: sociolingüística històrica, des de la metodologia variacionista; anàlisi dels discursos públics (periodisme, publicitat, comunicació audiovisual); i didàctica de la llengua i de la literatura, a partir sobretot de la seua implicació com a professor del Màster de Professorat. 